\title{
SEVERE ACUTE COPPER SULPHATE POISONING: A CASE REPORT
}

\author{
Andreja SINKOVIČ, Alenka STRDIN, and Franci SVENŠEK \\ Maribor Teaching Hospital, Maribor, Slovenia \\ Received in August 2007 \\ Accepted in January 2008
}

\begin{abstract}
As copper sulphate pentahydrate (CSP) is a common compound used in agriculture and industry, chronic occupational exposures to CSP are well known, but acute poisoning is rare in the Western world. This case report describes acute poisoning of a 33-year-old woman who attempted suicide by ingesting an unknown amount of CSP. On admission to the hospital, she had symptoms and signs of severe hemorrhagic gastroenteritis, dehydration, renal dysfunction and methaemoglobinaemia with normal serum copper level. Therapy included early gastric lavage, fluid replacement, vasoactive drugs, furosemide, antiemetic drugs, ranitidine, and antidotes methylene blue and 2,3-dimercaptopropane-1-sulphonate (DMPS). However, the patient developed severe intravascular haemolysis, acute severe hepatic and renal failure, as well as adrenal insufficiency. After prolonged, but successful hospital treatment, including haemodialysis and IV hydrocortisone, the patient was discharged with signs of mild renal and liver impairment. Our conclusion is that in severe cases of copper poisoning early supportive measures are essential. In addition, antidotes such as methylene blue for methaemoglobinaemia and chelating agent such as DMPS improve morbidity and survival of severely poisoned victims.
\end{abstract}

KEY WORDS: 2,3-dimercaptopropane-1-sulphonate, liver failure, methaemoglobinaemia, renal failure

Copper is an important element in plants, animals and humans. It serves as a cofactor in several enzyme reactions in the human body. Its homeostasis is well maintained by regulated absorption and excretion (1). Ingestion of $>1 \mathrm{~g}$ of a copper substance results in signs and symptoms of copper poisoning (2). Copper sulphate pentahydrate (CSP) is a common and easily available substance used in agriculture as a fungicide, herbicide, algicide, and fertilizer additive; it is also used in textile, timber, and leather industry, photography, veterinary practice, and human medicine as an antifungal agent, emetic and antidote, and in the past it was used in copper-plated tubing for haemodialysis (3).

Reports of accidental or suicidal poisoning are sporadic in western countries, but are very common in India, accounting for more than $40 \%$ of all poisonings (4).
Acute severe toxicity results in gastrointestinal injury with diarrhoea and melaena, haemolysis with haemoglobinuria, and/or haematuria, and hemolytic anaemia, kidney and liver failure, and even shock syndrome with profound hypotension, coma and lethal outcome. Early deaths are the consequence of shock, while late mortality is related to renal and hepatic failure (5).

To prevent lethal outcome in severe copper poisoning, in addition to early resuscitation measures it is important to start an early treatment with chelating agents. Among chelating agents such as dimercaprol, 2,3-dimercaptopropane-1-sulphonate (DMPS), penicillamine, or edetate calcium disodium, animal studies and some human case reports point to DMPS as a promising therapy $(6,7)$. This article presents a case of severe suicidal CSP poisoning, successfully treated by general supportive measures and DMPS. 


\section{CASE PRESENTATION}

A 33-year-old woman, who was previously healthy, intentionally ingested an unknown amount of highly concentrated CSP solution five hours before admission to the emergency department. Immediately after the ingestion she vomited blue gastric content more than 10 times and passed several loose stools. She reported weakness, but denied any pain or other symptoms, was fully conscious with blood pressure $(70 / 40) \mathrm{mmHg}[(93 / 53) \mathrm{hPa}$, heart rate 110 beats per minute, respiration rate 16 breaths per minute, oxygen saturation by pulse oxymetry $86 \%$, axillary body temperature $33.2^{\circ} \mathrm{C}$, and outstanding blue discoloration of the extremities distally to elbows and knees. The lungs were clear, the abdomen was non-tender with normal bowel sounds. The electrocardiogram revealed sinus tachycardia. Intravenous (IV) catheter was inserted, and blood samples taken for laboratory tests. Laboratory findings showed leucocytosis (leukocyte count $45.7 \times 10^{9} \mathrm{~L}^{-1}$ vs. normal levels $4 \times 10^{9} \mathrm{~L}^{-1}$ to $10 \times 10^{9} \mathrm{~L}^{-1}$ ), serum haemoglobin $180 \mathrm{~g} \mathrm{~L}^{-1}$ (normal range $120 \mathrm{~g} \mathrm{~L}^{-1}$ to $180 \mathrm{~g} \mathrm{~L}^{-1}$ ), haematocrit 0.558 (normal levels 0.37 to 0.54 ), red blood cell count $5.86 \times 10^{12} \mathrm{~L}^{-1}$ (normal range $4.2 \times 10^{12} \mathrm{~L}^{-1}$ to $6.3 \times 10^{12}$ $\left.\mathrm{L}^{-1}\right)$, metabolic acidosis with arterial $\mathrm{pH} 7.1$, bicarbonate $10.7 \mathrm{mmol} \mathrm{L}^{-1}$, base excess of $-18.5 \mathrm{mmol} \mathrm{L}^{-1}$, normal arterial $\mathrm{pCO}_{2}(4.76 \mathrm{kPa})$ and $\mathrm{pO}_{2}(15.35 \mathrm{kPa})$, serum methemoglobin $4.8 \%$ (upper normal limit $1.5 \%$ ), normal serum copper level of $19.9 \mu \mathrm{mol} \mathrm{L}^{-1}$ (normal range $12 \mu \mathrm{mol} \mathrm{L}^{-1}$ to $20 \mu \mathrm{mol} \mathrm{L}^{-1}$ ) and serum creatinine of $180 \mu \mathrm{mol} \mathrm{L}^{-1}$ (upper normal limit $97 \mu \mathrm{mol} \mathrm{L}^{-1}$ ). The patient received oxygen by face mask and IV fluids. Gastric lavage was performed and activated charcoal administered.

At this point it was clear that the patient suffered from a severe form of copper sulphate poisoning with signs of acute gastroenteritis, dehydration with evolving renal failure, metabolic acidosis and methaemoglobinaemia. The patient was admitted to the medical intensive care unit (MICU) and further treated with IV fluids, bicarbonate, dopamine $\left(10 \mu \mathrm{g} \mathrm{kg}^{-1} \mathrm{~min}^{-1}\right)$, an antiemetic, ranitidine, IV furosemide to enhance diuresis, and methylene blue at the dose of $2 \mathrm{mg} \mathrm{kg}^{-1}$ to treat methaemoglobinaemia. Within the next few hours DMPS (Dimaval ${ }^{\circledR}$ ) treatment was initiated at the IV dose of $250 \mathrm{mg}$ every four hours. After the first 24 to 48 hours the patient was circulatory stable with a normal urine output due to treatment, though severe haemorrhagic gastroenterocolitis with melaena and haematemesis was still present. Her renal function improved, urine volume was more than $5 \mathrm{~L}$ per day, and creatinine level dropped. In addition, severe intravascular haemolysis developed. The patient became severely anaemic with haemoglobin level of $62 \mathrm{~g} \mathrm{~L}^{-1}$. Lactate dehydrogenase (LDH) level was $80 \mu \mathrm{kat} \mathrm{L}^{-1}$ (upper normal limit $4.13 \mu \mathrm{kat}$ $\mathrm{L}^{-1}$ ), haptoglobin level less than $0.09 \mathrm{~g} \mathrm{~L}^{-1}$ (normal range $0.34 \mathrm{~g} \mathrm{~L}^{-1}$ to $2.00 \mathrm{~g} \mathrm{~L}^{-1}$ ), and free serum haemoglobin $1373 \mathrm{mg} \mathrm{L}^{-1}$ (normal range $50 \mathrm{mg} \mathrm{L}^{-1}$ to $400 \mathrm{mg} \mathrm{L}^{-1}$ ). Acute parenchymal liver damage developed with a rise in aspartate aminotransferase level to $26.32 \mu \mathrm{kat} \mathrm{L}^{-1}$ (upper normal limit $0.58 \mu \mathrm{kat}$ $\mathrm{L}^{-1}$ ) and alanine aminotransferase to $16.19 \mu \mathrm{kat}$ $\mathrm{L}^{-1}$ (upper normal limit $0.74 \mu \mathrm{kat} \mathrm{L}^{-1}$ ), decreased albumin level to $24 \mathrm{~g} \mathrm{~L}^{-1}$ (normal range $32 \mathrm{~g} \mathrm{~L}^{-1}$ to 55 $\mathrm{g} \mathrm{L}^{-1}$ ), prolonged prothrombin time to $0.27 \mathrm{~s}$ (normal range $0.7 \mathrm{~s}$ to $1.2 \mathrm{~s}$ ), and increased total bilirubin to $511 \mu \mathrm{mol} \mathrm{L}^{-1}$ (normal range $<17 \mu \mathrm{mol} \mathrm{L}^{-1}$ ) and conjugated bilirubin to $500 \mu \mathrm{mol} \mathrm{L}^{-1}$ (normal range $<5 \mu \mathrm{mol} \mathrm{L}^{-1}$ ). Anaemia was the consequence of haemolysis and gastrointestinal bleeding. The patient was treated with transfusions of packed red blood cells, fresh frozen plasma, human albumin, IV fluids, and particularly high-concentration glucose solutions (1000 mL of $20 \%$ glucose) to enable liver reparation. She received ranitidine IV. After 48 hours in the hospital, the patient developed signs of sepsis with fever of 39 ${ }^{\circ} \mathrm{C}$, leucocytosis (leukocyte count $60.49 \times 10^{9} \mathrm{~L}^{-1}$ vs. normal range $4 \times 10^{9} \mathrm{~L}^{-1}$ to $10 \times 10^{9} \mathrm{~L}^{-1}$ ) with left shift (37\% of band neutrophils), tachycardia 110 bpm to $120 \mathrm{bpm}$, respiration rate of 16 to 20 breaths per minute, C-reactive protein (CRP) of $156 \mathrm{mg} \mathrm{L}^{-1}$ (upper normal limit $5 \mathrm{mg} \mathrm{L}^{-1}$ ) and procalcitonin level of $10 \mathrm{ng} \mathrm{mL}^{-1}$ (upper normal limit $0.5 \mathrm{ng} \mathrm{mL}^{-1}$ ). A broad spectrum antibiotic was started (meropenem $1 \mathrm{~g}$ every eight hours). After a few days, the patient remained severely anaemic despite the treatment, liver damage was progressing with a further rise in transaminase levels and a further fall in synthetic function. Acute renal failure developed with an increase in serum creatinine to $679 \mu \mathrm{mol} \mathrm{L}^{-1}$ and onset of anuria. The continuous veno-venous haemodiafiltration (CVVHDF) was initiated and DMPS discontinued. The patient was still receiving other supportive measures, including blood transfusions, human albumin, IV fluids, broad spectrum antibiotic and parenteral nutrition. Treatment with hydrocortisone $100 \mathrm{mg}$ every six hours was started due to documented adrenal insufficiency (after a high-dose ACTH stimulation test, cortisol level was $30 \mathrm{nmol} \mathrm{L}^{-1}$ vs. normal range 260 
nmol L-1 to $760 \mathrm{nmol} \mathrm{L}-1$. After 10 days at the intensive care unit, gastroisntestinal signs and signs of severe intravascular haemolysis resolved. The patient was anuric for 11 days and required CVVHDF, and later intermittent dialysis. She gradually became oliguric. However, signs of acute parenchymal liver damage with increased transaminase, bilirubin and prolonged prothrombin time persisted throughout her stay in the intensive care unit. She was fully alert all the time.

After 14 days the patient was transferred to the nephrology ward, requiring intermittent dialysis. Gradually, she was able to eat and to pass normal stools. Her liver and renal function gradually improved.

The patient was discharged from the hospital after 5 weeks. At discharge, the renal function was still mildly impaired with normal diuresis and moderately elevated serum creatinine level $\left(240 \mu \mathrm{mol} \mathrm{L}^{-1}\right)$, but no longer requiring dialysis. The liver function showed a slightly elevated aspartate aminotransferase $(3.41 \mu \mathrm{mol}$ $\left.\mathrm{L}^{-1}\right)$, alanine aminotransferase $\left(3.49 \mu \mathrm{mol} \mathrm{L}^{-1}\right)$, total $\left(130 \mu \mathrm{mol} \mathrm{L}^{-1}\right)$ and conjugated $\left(97 \mu \mathrm{mol} \mathrm{L}^{-1}\right)$ bilirubin. The haemoglobin level remained unchanged and the gastrointestinal function was normal. She no longer required adrenal substitution, as adrenal insufficiency resolved. Serum cortisol was $337 \mathrm{nmol} \mathrm{L}^{-1}$.

Months after discharge her renal function was still minimally impaired. Creatinine level was $110 \mu \mathrm{mol} \mathrm{L}^{-1}$ and renal clearance of $\mathrm{Cr}$-ethylenediaminetetraacetic acid (EDTA) was $75 \mathrm{~mL} \mathrm{~min}^{-1}$ per $1.72 \mathrm{~m}^{2}$. The liver function tests and total blood count were normal. She was leading a normal life.

\section{DISCUSSION}

Clinical features of copper poisoning are the consequence of several mechanisms, resulting in the dysfunction of several organ systems. After oral ingestion, copper-containing substances cause immediate irritation and erosion of the gastrointestinal epithelium (2). Systemic copper toxicity is the consequence of its ability to participate in the production of free oxygen radicals within the cells, resulting in severe intra-nuclear and cytoplasmic injury and cell death $(2,3)$. It also alters cellular membranes by lipid peroxidation and cellular proteins by denaturation (2).

In our patient, systemic copper toxicity affected several organs, including gastrointestinal tract, liver and kidneys. Haemolysis, rhabdomyolysis, and methaemoglobinaemia were also registered.

Immediate gastrointestinal injury with vomiting, diarrhoea, blue staining of oral and oesophageal mucosa, haematemesis and melaena were severe in our patient and contributed to substantial blood loss and hypotension on admission. However, gastrointestinal toxicity is also present in cases of parenteral poisoning, suggesting that gastrointestinal manifestations are not the only consequence of a direct contact of copper with the digestive system (5).

Copper in the form of CSP can cause direct damage to the erythrocyte membranes as well as oxidative damage within the erythrocyte. Copper(II) ions can oxidise haem iron to form methaemoglobin (8).

In our patient, signs of intravascular haemolysis occurred within 24 hours of ingestion (8). However, anaemia developed after the first 24 hours and was obviously the consequence of the combined effect of intravascular haemolysis and gastrointestinal blood loss. Methaemoglobinaemia was already suspected on admission due to bluish discoloration of the arms and was demonstrated by increased methaemoglobin level. It was treated immediately with the antidote methylene blue.

Acute hepatic and renal failure are present only in severe CSP poisoning. Acute liver failure, and/or icterus, and/or hepatomegaly, and/or increased serum transaminases, and/or prolongation of prothrombin time are among signs of the hepatotoxic CSP effect. $(2,4,5)$.

Acute renal failure, being a common complication of severe CSP poisoning, is a combination of direct toxic effects on the proximal tubules, reduced renal perfusion secondary to hypovolemia and intravascular haemolysis. Most often renal failure develops 3 to 4 days after acute poisoning and may be prolonged, as was the case with our patient. There is evidence that renal recovery is incomplete $(2,8,9)$. In our patient there was a prolonged period of oliguria and haemodialysis dependency, and even months after the poisoning her serum creatinine level was slightly increased $\left(110 \mu \mathrm{mol} \mathrm{L}^{-1}\right)$ and her renal clearance

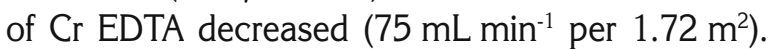
Unfortunately, kidney biopsy was not performed.

Among organ systems that are rarely directly affected in acute CSP poisoning are the cardiovascular system, skeletal muscles, central nervous system, and endocrine system (10). In our patient we 
observed hypotension with shock, but ascribed it to the combined effect of gastrointestinal bleeding and dehydration. However, we observed adrenal insufficiency, which is also frequently encountered in critically ill patients with infection and sepsis, as demonstrated by decreased serum cortisol level. However, it could reflect direct copper toxicity that has not been described yet.

The clinical presentation of copper poisoning may be further aggravated by infection and sepsis with a multi-organ dysfunction. Translocation of intestinal bacteria is the most probable source of respiratory infection and possible sepsis, suspected in our patient and confirmed by increased serum CRP and procalcitonin level (11).

The amount of CSP ingested by our patient was unknown, but had to be substantial judging by very early signs of gastrointestinal injury and multi-organ dysfunction. However, no clear data exist on the dose/ effect relationship and lethal dose. In most reports it took at least $1 \mathrm{~g}(4,5)$ of oral copper to produce a toxic effect, but at this oral dose of CSP, a few fatal outcomes have also been reported (12, 13). Early death is attributed to hypotension and shock, late death to hepatic and renal failure (5).

In acute poisoning, whole blood copper concentrations correlate better with the severity of poisoning than do serum copper levels. In our patient however, we estimated only the serum and not whole blood copper level or urinary copper excretion.

The use of DMPS seems most promising among chelating agents. It is a water-soluble analogue of dimercaprol and also forms stable complexes with heavy metals in the cell and removes them from the active sites of enzymes. As DMPS and its heavy-metal complexes are excreted predominantly by the kidney, caution is necessary in severe renal failure. DMPS seems to be the most effective antidote in severe copper poisoning and has the most favourable adverse effect profile according to animal studies $(2,6,7)$. However, there are no controlled data regarding the use of any chelating agent in acute CSP poisoning in humans (3). We used DMPS for a few days in our patient, but stopped its administration due to acute renal failure necessitating haemodialysis. According to reports, haemodialysis is of no value in copper elimination, but is effective in the treatment of coexisting acute renal failure (8).

To conclude, CSP ingestion can lead to severe and life-threatening multi-organ dysfunction. In severe cases, early supportive measures are essential in addition to antidotes such as methylene blue in methaemoglobinaemia and chelating agents such as DMPS to improve survival of severely poisoned victims.

\section{REFERENCES}

1. Pandit AN, Bhave SA. Copper metabolic defects and liver disease: Environmental aspects. J Gastroenterol Hepatol 2002;17(Suppl 3):S403-7.

2. Oon $\mathrm{S}$, Yap $\mathrm{CH}$, Ihle BU. Acute copper toxicity following copper glycinate injection. Intern Med J 2006;36:7413.

3. Beer ST, Bradberry SM, Vale JA. UKPID Monograph. Copper Sulfate. UK National Poisons Information Service. Birmingham (UK): West Midlands Poisons Unit, City Hospital NHS Trust. 1998 [displayed May 2007]. Available at http://www.intox.org/databank/ documents/chemical/copper/ukpid57.htm

4. Agarwal BN, Bray SH, Bercz P, Plotzker R, Labovitz E. Ineffectiveness of hemodialysis in copper sulphate poisoning. Nephron 1975;15:74-7.

5. Oldenquist G, Salem M. Parenteral copper sulfate poisoning causing acute renal failure. Nephrol Dial Transplant 1999;14:441-3.

6. Torres Alanis O, Garza-Ocanas L, Bernal MA, PineyroLopez A. Urinary excretion of trace elements in humans after sodium 2,3-Dimercaptopropane-1-sulfonate challenge test. Clin Toxicol 2000;38:697-700.

7. Mitchell WM, Basinger MA, Jones MM. Antagonism of acute copper(II)-induced renal lesions by sodium 2,3Dimercaptopropanesulfonate. Johns Hopkins Med J 1982;151:283-5.

8. Yang CC, Wu ML, Deng JF. Prolonged hemolysis and methemoglobinemia following organic copper fungicide ingestion. Vet Hum Toxicol 2004;46:321-3.

9. Bhowmik D, Mathur R, Bhargava Y, Dinda AK, Agarwal SK, Tiwari SC, Dash SC. Chronic interstitial nephritis following parenteral copper sulfate poisoning. Ren Fail 2001;23:731-5.

10. Takeda T, Yukioka T, Shimazaki S. Cupric sulfate intoxication with rhabdomyolysis, treated with chelating agents and blood purification. Intern Med 2000;39:253-5.

11. Levy MM, Fink MP, Marshall JC, Abraham E, Angus D, Cook D, Cohen J, Opal SM, Vincent JL, Ransay G. 2001 SCCM/ESICM/ACCP/ATS/SIS International sepsis definitions conference. Crit Care Med 2003;31:12506.

12. Liu J, Kashimura S, Hara K, Zhang G. Death following cupric sulfate emesis. J Toxicol Clin Toxicol 2001;39:161-3.

13. Stein RS, Jenkins D, Korns ME. Letter: Death after use of cupric sulfate as emetic. JAMA 1976;235:801. 


\section{Izuleček}

\section{TEŽKA AKUTNA ZASTRUPITEV Z BAKROVIM SULFATOM - PRIKAZ PRIMERA}

Bakrov sulfat pentahidrat (BSP) se pogosto uporablja v kmetijstvu in industriji, zato so kronične poklicne zastrupitve dobro poznane, akutne zastrupitve pa so v razvitem svetu redke. Opisujemo primer akutne zastrupitve zaradi poskusa samomora pri 33-letni ženski zaradi zaužitja neznane količine BSP. Ob sprejemu so bili prisotni simptomi in znaki težkega hemoragičnega gastroenteritisa, izsušitve, razvijajoče se ledvične odpovedi in methemoglobinemije z normalno vrednostjo bakra v serumu. Takoj smo sprali želodec in začeli iv. dajati tekočine, kateholamine, furosemid, antiemetik, ranitidin in antidota metilensko modrilo in 2,3dimerkaptopropan-1-sulfonat (DMPS). Kljub zgodnjim ukrepom se je razvila težka znotrajžilna hemoliza, težka akutna jetrna in ledvična odpoved ter odpoved nadledvičnice. Po dolgem, vendar uspešnem zdravljenju, vključno z zdravljenjem s hemodializo in iv. steroidi, je bila bolnica odpuščena z znaki blage ledvične in jetrne okvare. Zaključujemo, da je pri težkih zastrupitvah z bakrom zgodnje simptomatsko zdravljenje prvi najpomembnejši ukrep. Uporaba antidotov, kot je metilensko modrilo pri methemoglobinemiji, in ionskih izmenjevalcev, kot je DMPS, pa dodatno zmanjša obolevnost in izboljša preživetje težko zastrupljenih.

KLJUČNE BESEDE: 2,3-dimerkaptopropan-1-sulfonat, jetrna odpoved, ledvična odpoved, methemoglobinemija, metilensko modrilo

\section{CORRESPONDING AUTHOR:}

Andreja Sinkovič, MD, Ph.D.

Department of Medical Intensive Care

Maribor Teaching Hospital,

Ljubljanska 5, SI-2000 Maribor, Slovenia

E-mail: andreja.sinkovic@guest.arnes.si 